\title{
Carst Marble on Tyrnyauz Deposit
}

\author{
Vladimir V. Khaustov, Ignat M. Ignatenko, L.E. Kruglova, A.I. Karnjushkin, A.V. Shleenko
}

\begin{abstract}
The karst of marbles is considered as the least studied type of karst. Here we have pinpointed the karst area of the ore field of the Tyrnyauz deposit. Lithological and petrographic characteristics of the skarned marbles of Tyrnyauz are given, their chemical activity is determined. Tectonogenic fissure-karst drainage system of the deposit is analyzed. The main factors of karst formation have been determined and the development of the karst marbles of the Tyrnyauz ore field at various depths is predicted.
\end{abstract}

Keywords : karst, marbles, karst formation, groundwater, tectonics, fracturing, modelling.

\section{INTRODUCTION}

Karst marbles are less studied than other types of karst. The founder of scientific karstology G.A. Maksimovich [1], considered the karst of marbles as a peculiarity of the carbonate karst [2]. He pointed out that calcium dolomite and transitional varieties of marbles occur in the Caucasus, the Urals, the Baltic shield, Siberia, the Far East, Central Asia and in many countries of the world. The strategic age interval of them is very wide - from the Archaean to the Mesozoic ones. There is a variety of karst forms of bare, covered and closed karst marbles [3]. Marbles differ from limestones with lower solubility, so they are less common in caves of larger sizes than caves of limestone and gypsum.

\section{MATERIALS AND RESEARCH METHODS}

G.A. Maksimovich made a regionalization of the karst of the territory of the former USSR on a tectonic basis, highlighting the karstic country of the Greater Caucasus, which is divided into karst areas and regions [4].

Karst phenomena in the tectonic zones of the Main and Forward ranges of the Greater Caucasus are limited by narrow bands of marble outcrops and marbled limestones of the Carboniferous and Mesozoic and are associated with cracks and faults on contacts with other rocks.

\section{RESULTS AND DISCUSSION}

There is an example is the karst region of the Tyrnyauz contact-metasomatic tungsten-molybdenum deposit, which is located at the intersection of the Tyrnyauz-Pshekishsky

Revised Manuscript Received on July 22, 2019.

* Correspondence Author

Vladimir V. Khaustov, Belgorod State University, 85 Pobeda St, Belgorod, 308015, Russia.

Ignat M. Ignatenko, Belgorod State University, 85 Pobeda St, Belgorod, 308015, Russia.

L.E. Kruglova, Sochi State University, 26-a Sovetskaya St.,Sochi, 354000, Russia.

A.I. Karnjushkin, Technical University named after Bauman, 5/1 Second Baumanskaya St., Moscow, 105005, Russia

A.V. Shleenko, Southwest State University, 9450 years of October St. 305040, Russia.
Suture Zone and the Transcaucasian Transverse Uplift $42 \mathrm{~km}$ to the west of the Elbrus volcano at an altitude of 2-4 thousand meters above sea level. The karst region is located in the fault zone of the northwestern strike in the Paleozoic formations (clayey shales, sandstones, marbles, tuffites) eroded by young alpine leucocratic and porphyry granites. Structurally, the deposit represents a horseshoe-shaped anticlinal fold, which in the core and on the wings is made up of marbles covered with hornfels of the sandy-slate (Pastukhov) suite, the latter being exposed in the syncline and anticline wings (Figure 1) [5]

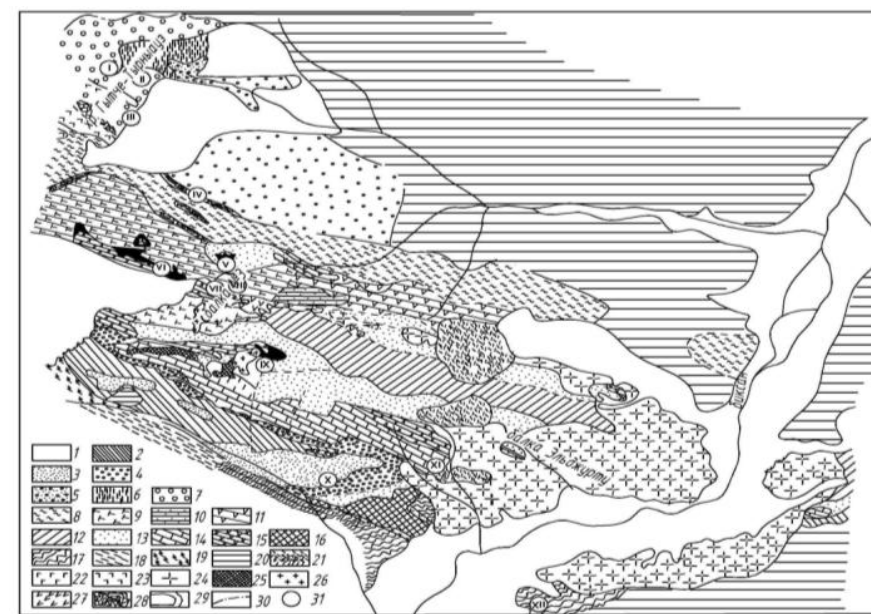

Figure 1: Scheme of the geological structure of the ore field of the Tyrnyauz deposit Explication to Fig. 1. Scheme of the geological structure of the ore field of the Tyrnyauz deposit:

1 - Quaternary sediments; 2 - black shales of the Mukulan suite; 3 - sandstones of the Mukulan Formation; 4 conglomerates of the Mukulan suite; 5 - red sandstones; 6 dark gray siltstones and shales; 7 - conglomerates and sandstones; 8 - phyllites; 9 - volcanogenic formation; 10 dark-gray arkose sandstones of the greenstone formation; 11 - diabase, porphyritis; 12 - quartz plagioporphyri; 13 - biotite hornfels; 14 - layered marbles; 15 - massive marbles; 16 - the Eljurta suite; 17 - migmatites; 18 - mica schists; 19 - granite gneiss; 20 - crystalline schists and gneisses; 21 - liparites; 22 - augite porphyrites; 23 - quartz keratophyres; 24 - Eljurta granite; 25 - breccias of biotite hornfelses; 26 - leucocratic granitoids; 27 - ultrabasites; 28 - quartz-carbonate rocks; 29 skarns; 30 - tectonic contacts; 31 - ore occurrences: I antimony deposit Gitsche-Tyrnyauz, site number 3; II - the same, section number 2; III - the same, section number 1; IV-VI - geophysical anomalies №1-3; VII - sulfide deposit of Tyrnyauz-Su; VIII - gold-arsenopyrite veins of beam No. 3; IX - the Tyrnyauz deposit; X - Mukulan deposit of andalusite schists; XI - polymetallic deposit Maly Mukulan; XII Tyu-ty deposit. 
Homogeneous and layered marbles of the Upper Devonian age lie in the form of numerous large interlayers among the rocks of the Pastukhov set. Homogeneous marbles of large and medium grains are dark gray rocks of banded texture. They contain in addition to carbonate minerals (calcite, dolomite) impurities of pyroxenes and colorless mica. In dark bands, the content of impurities (skarn minerals, carbonaceous matter) can reach $10 \%$. In some areas, marbles intersect with a dense network of calcite and skarn veins and veins, giving them a breccia-like appearance [6].

In hydrogeological terms, marbles differ from other basic rocks of the ore field by relatively increased reservoir properties, chemical activity (the ability to interact with natural solutions), which imposes a significant imprint on the processes of their interaction with groundwater.

The chemical activity of marbles and other rocks of the Tyrnyauz deposit with respect to hydrogen ions was determined by the NA method. Udodova and I.V. Kristaleva [7], based on the ability of rocks and minerals to change the $\mathrm{pH}$ of solutions (Table). It turned out that the marbles, according to AI classification. Perelman [8], are strongly active rocks - precipitators of heavy metals from natural waters (reaction in acidic solution $\mathrm{AK}(3.0)=8.75$; in distilled water $\mathrm{AB}(6.2)=9.30)$.

Within the Tyrnyauz deposit, various karst forms are developed in marbles: caverns, voids, caves reaching in the width of 2-3 m. The thicknesses of marbles as a rule are karst uniformly in their distribution, but larger cavities are confined to local zones of faults.

A tectonogenic fissure-karst drainage system of the deposit is represented by a network of large cracks of different opening, which have relatively high water conductivity. These cracks are imposed on a dense network of microcracks, less often pores, and play the role of peculiar underground galleries draining the water contained in the watered blocks of the field. Three separate basins of fissured-karst waters are distinguished: the Central ore field, the marbles of the peak "Vera" and the source of Tyrnyauz-Su (Fig. 2, 3).

Table 1:The chemical activity of rocks in the Tyrnyauz deposit

\begin{tabular}{|c|c|c|c|}
\hline The name of rocks & $\begin{array}{c}\mathrm{A} \mathrm{K}( \\
3,0)\end{array}$ & $\begin{array}{c}\text { A B ( } \\
6,2) \\
\end{array}$ & Activity \\
\hline Marble & 8.7 & 9.3 & \multirow{6}{*}{$\begin{array}{l}\text { IV. VERY } \\
\text { ACTIVE }\end{array}$} \\
\hline $\begin{array}{l}\text { Pyroxene-garnet } \\
\text { skarn }\end{array}$ & 7.4 & 9.2 & \\
\hline Biotite horn & 6.1 & 9.4 & \\
\hline $\begin{array}{l}\text { Biotite-amphibole } \\
\text { hornfels }\end{array}$ & 5.8 & 9.4 & \\
\hline Piroxenite & 6.2 & 9.1 & \\
\hline Liparite & 5.9 & 9.0 & \\
\hline $\begin{array}{l}\text { Leucocratic } \\
\text { granitoids }\end{array}$ & 5.3 & 8.9 & \multirow{3}{*}{ Enough active } \\
\hline $\begin{array}{l}\text { Pyroxene-plagiocla } \\
\text { se corneal }\end{array}$ & 4.5 & 9.0 & \\
\hline Serpentinite & 3.5 & 7.0 & \\
\hline The Eljurta granite & 3.4 & 8.7 & \multirow{3}{*}{ Low active } \\
\hline Cristalline shale & 3.2 & 8.7 & \\
\hline Conglomerate & 3.4 & 6.7 & \\
\hline
\end{tabular}

Note: Chemical activity: AK (3.0) in acidic solutions with $\mathrm{pH}=3.0 ; \mathrm{AB}(6.2)$ - in disciplined water with $\mathrm{pH}=6.2$.

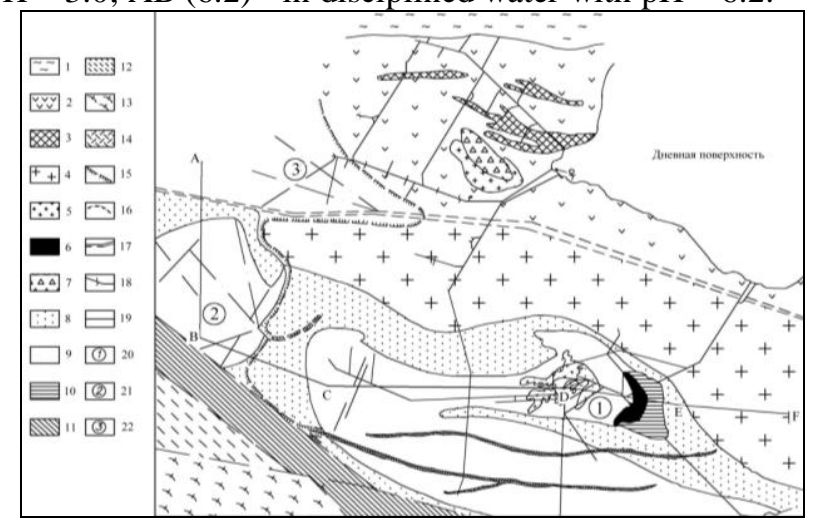

Figure 2: Schematic geological plan of the horizon $2317 \mathrm{~m}$ of the Tyrnyauz deposit.

They are divided among themselves by rocky fractured water bodies, as a result of which they are actually hydraulically connected and represent a single system of fissured-karstic waters with a common piezometric level and a very heterogeneous filtration field controlled by the source of Tyrnyauz-Su. Water exchange between basins occurs by infiltration of water from glacial moraines into the cavities of local karst in the marbles of the source area of Tyrnyauz-Su then, according to the system of fissures of the "Vera Peak" marbles penetrating into the karst voids, and further along the cracks of the hornblock block, water enters the local stepped karst developed in the massive and layered marbles of the basin of the Central ore field. The stream of fissured-karst waters has a main direction to the southeast and northeast towards local erosion bases. The crest of the Eljurta granite separates the streams.

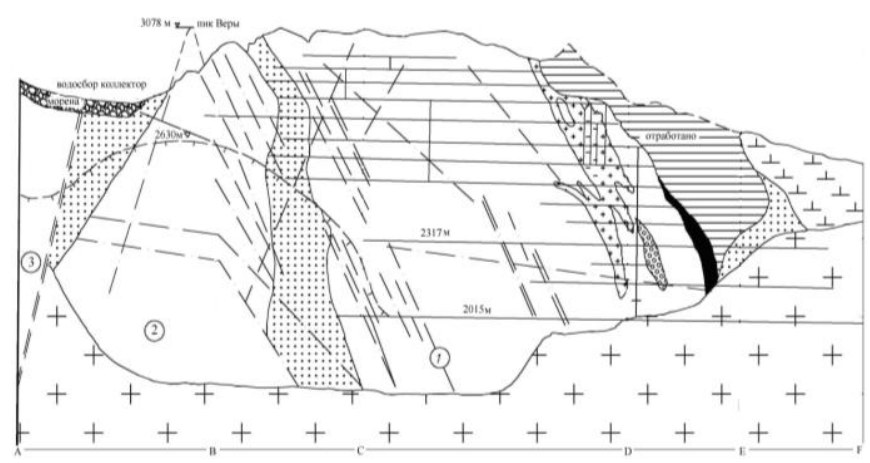

Figure 3: Schematic geological section along the line ABC-D-E-F to the schematic geological plan (see Figure 2) Explication to Fig. 2. Schematic geological plan of the horizon $2317 \mathrm{~m}$ of the Tyrnyauz deposit:

1 - conglomerates; 2 - hornfels on sedimentary rocks; 3 ultrabasic rocks; 4 - Eljurta granite; 5 - leucocratic granitoids; 6 - skarns; 7 - conglobrecia; 8 - sandstones of the Mukulan suite; 9 - carbonate rocks (massive and layered marbles); 10 - spent rock massif; 11 - black shales of the Mukulan suite; 12 - granite gneiss; 13 - dark gray siltstones and shales; 14 - liparites; 15 - the boundaries of the distribution of fissured-karst waters; 16 - conditional surface of fissured-karst waters; 17 zone of crushing of the Central fault; 18 - disjunctive disorders; 19 - horizontal

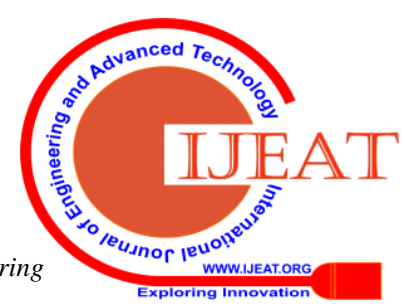


mine workings; 20 - basin of fissured-karst water of marbles of the Central ore field; 21 - basin of fissured-karst water of the marbles of the peak of the Faith; 22 - basin of fissured-karst waters of marbles in the district of the source of Tyrnyauz-Su.

The feeding area of fissured-karst waters is the upper reachers of the river Tyrnyauz-Su. Their natural discharge occurs on the slopes of the Ullu-Tyrnyauz ridge, but most of the water is drained by mine workings, where significant water inflows are observed, often with a head pressure of up to 50 atmospheres. There is also a flow of fissured-karst waters into other lithological complexes of rocks, located hypsometrically below the carbonate rocks. The flow rates of sources fluctuate depending on the amount of precipitation and seasonal snowmelt.

The karst cavities are almost always flooded: at the first opening, the fountains of pressurized waters beat them with rock excavations. The feeding zone of all fissured-karst waters is the zone of the upper reaches of the river. Tyrnyauz-Su. Natural unloading of fissured-karst waters occurs along the slopes of the Ullu-Tyrnyauz ridge, but the largest part of them is drained by mine workings. Here fissured-karst water forms powerful water inflows. This is the kapes from the cracks and karst cavities in the roof and sides of the excavations, and powerful jets with a head up to 50 atmospheres. In addition, there is a flow of fissured-karst waters into other lithological complexes of rocks, located hypsometrically below the carbonate ones.

An example of access to the surface of fissured-karst waters is the source of Tyrnyauz-Su - typically karst, confined to marbles, which adjoin the central fault and wedge out near it. On the way of karst waters, the valley of the stream is crossed by the northern ridge of the El'jurta granites, which create a backwater to the underground waters, and they bypass it to rush to the river. Baksan. Thus, part of the water was discharged through the source of Tyrnyauz-Su, the rest of the cracks of the southeast strike to the karst cavities of the marbles of the Vera Peak region moves south, flooding the mine. The flow rate of the source fluctuated depending on precipitation precipitation and seasonal snowmelt. In recent years, due to drilling wells that cut cracks and karst cavities in communication with the source, the flow rate of the latter has significantly decreased, and in 1986 the source was dry (the average multi-year source flow was $1301 / \mathrm{s}$ ).

The flow of fissured-karst water into the mine workings and the worked-out space fundamentally changes the conditions for the formation of their resources and regime, and can also significantly complicate the conduct of mining operations. At the Tyrnyauzskoye field, sudden breakthroughs of huge volumes of karst water have already taken place, along with sandy-argillaceous material, often filling karst voids. Thus, during the penetration of the cross-hole No. 2 in the tunnel No. 16, a gaping cavity was opened, confined to a tectonic zone passing along the contact of the marbles with the skarns. After blasting at the face from this cavity, water with a flow rate of $4001 / \mathrm{s}$ broke through.

The chemical composition of fissured-karst waters of marble bicarbonate-calcium with mineralization from 0.15 to $0.40 \mathrm{~g} / \mathrm{l}$ and $\mathrm{pH}-6-7.4$, and the temperature varies from 5 to $7 \mathrm{C}^{\circ}$ [9].
Within the deposit, two hydrogeochemical zones are distinguished: the upper and the lower zones, characterized by feeding conditions, circulation and unloading, and by the chemical composition of the waters [9]. Therefore, both meteoric waters of the upper hydrogeochemical zone of the hydrocarbonate-calcium (magnesium) composition and carbonic-alkaline-alkaline waters with increased mineralization (up to $8 \mathrm{~g} / \mathrm{l}$ ) of the lower hydrogeochemical zone take part in the karst formation. The composition of the waters of the lower zone is formed with the participation of oxidizing sulphide mineralization, which significantly enhances their aggressiveness with respect to marbles. It is known that sulfuric acid is an important factor determining the aggressive properties of natural waters, which in natural conditions is formed mainly due to the oxidation of sulfides and sulfur. It should also be noted that marbles dissolve more intensely in water containing free carbon dioxide or other mineral or organic acids. In addition, the solubility of marbles (as well as of other carbonate rocks) can increase if some salts, for example $\mathrm{NaCl}$, are contained in water [10].

Consequently, the given types of underground waters of the deposit are to varying degrees aggressive against carbonate rocks. Their dissolving power is determined using the software complex "WATER" (author VN Ozyabkin). The software complex "WATER" allows modeling the process of establishing the physicochemical equilibrium of groundwater with six minerals: calcite, magnesite, strontianite, anhydrite, gypsum and celestine under various conditions of $\mathrm{CO}_{2}$ exchange between the liquid and gaseous phases. There are two options for modeling (according to the user's choice): 1) there is no exchange of $\mathrm{CO}_{2}$ between water and the gaseous phase, i.e. the sum of the concentrations of $\mathrm{CO}_{2}+\mathrm{HCO}_{3}+\mathrm{CO}_{3}$ is known and constant, only redistribution of these forms is possible; 2) the partial pressure of $\mathrm{CO}_{2}$ is set and changed, its excess is released from the solution, and the deficit is compensated for by absorption. It is established that to achieve carbonate equilibrium in the waters of the lower and upper hydrochemical zones, as well as the waters of the mixing zone, the deficit of $\mathrm{CaCO}_{3}$ is 727 , 80 and $164 \mathrm{mg} / 1$, respectively [6]. Consequently, the maximum solubility with respect to marbles is characteristic of deep soda waters and is due to temperature gradients and $\mathrm{CO}_{2}$. At the same time, it should be noted that underground waters of this type were discovered in the field only in the late 1970 s, but their inflow into the mine workings increased in the last years of field exploitation due to the constant expansion of the mining front, and as a result the hydrogeological service of the mine noted an intensification of karst formation [11].

It is well known that tectonics has a significant effect on watering of deposits of solid minerals, as karst processes develop most intensively in tectonic cracks and faults. In mountain-folded areas, where carbonate rocks are intensively and repeatedly subjected to dislocation, local karst usually affects them throughout the power. In this regard, we should expect the so-called local (concentrated) zakarstovannost marbles of the Tyrnyauz ore field at various depths, which is confirmed by field studies in deep mine workings $[6,12]$. 


\section{CONCLUSION}

Thus, tectonic, geomorphological and hydrogeological conditions, as well as human activity, contribute to the processes of karst formation in the karstic area of the ore field of the Tyrnyauz tungsten-molybdenum deposit. Karst marbles belong to the closed (covered) type of karst and is confined to the high-altitude zone of active water exchange of the Forward Ridge of the Greater Caucasus. At the same time, the development of karst in marbles is controlled by discontinuous tectonics and fracturing. Karst forms develop on two floors: the upper one - under the influence of fissured waters of meteoric origin and the lower one - with the participation of carbonic-alkaline-hydrous soda-type waters. The processes of oxidation of sulphide mineralization and mining work strengthen their aggressiveness. However, the marbles of the deposit contain impurities of non-carbonate minerals, have a banded texture and a full-crystal structure, have low solubility in comparison with limestones. Therefore, there is less variety of karst forms in them, the deep forms of the closed type of karst of small sizes prevail.

\section{REFERENCES}

1. Khaustov, V.V., 2009. Underground waters and deep geodynamics of Tyrnyauz. Publishing house of Kursk State Technical University, Kursk, p. 180. (In Russian)

2. Khaustov, V.V., Ustiugov, D.L., 2017. Formation of drainage waters of Tyrnyauz deposit in ecological aspect. IOP Conf. Series: Earth and Environmental Science. №87, p. 5.

3. Khaustov, V.V., Filonova, M.A., 1989. About karst formation in the Tyrnyauz deposit. Bulletin of Leningrad State University, ser.7., p.74-76. (In Russian)

4. Korotkevich, G.V., 1962. Some genetic features of superficial karst forms of areas of closed karst. General questions of karst studies. Publishing House of the USSR Academy of Sciences, Moscow, p. 165-176. (In Russian)

5. Lyakhovich, V.V., 1976. Connection of mineralization with magmatism (Tyrnyauz). Nauka, Moscow, p. 424. (In Russian)

6. Maksimovich, G.A., Kondakov, V.M., 1978. Karst of marbles, dolomites, reefs, calcareous tuffs and halogen deposits. Perm, p.3-4. (In Russian)

7. Maximovich, G.A., 1969. Fundamentals of Karstology. Perm, p. 529. (In Russian)

8. Maximovich, G.A., 1962. Tectonic regularities of karst distribution on the territory of the USSR. General questions of karst studies. Publishing House of the USSR Academy of Sciences, Moscow, p.40-54. (In Russian)

9. Nezhdanova, I.K. Suetin, Yu.P. Sveshnikov, G.B., 1986. To the geochemistry of groundwaters of the Tyrnyauz tungsten-molybdenum deposit. In Sat. Theses of the reports of the All-Union Conference "Hydrogeochemical Exploration of Mineral Deposits". Tomsk, p. 36-37. (In Russian)

10. Perelman, A.I. Geochemistry., 1989. Higher School, Moscow, p. 527. (In Russian)

11. Udodov, I.A., Parilov. Yu.S., 1962. Experience in hydrogeochemical research in Siberia. Higher education, Moscow, p.190. (In Russian)

12. Yezhov, Yu.A., Lysenin G.P., Andreychuk VN, Dublyansky Yu.V. 1992. Karst in the Earth's crust: distribution and basic types. Siberian Branch of the Russian Academy of Sciences, Novosibirsk, p. 76. 